\title{
Citizenship, Affiliation and Exclusion: Perspectives from the South
}

\section{Naila Kabeer*1}

\section{Introduction}

Citizenship is a way of defining personhood, which links rights and agency: 'citizenship as rights enables people to act as agents' (Lister 1997). It is consequently a powerful word, with connotations of respect, rights and dignity. As Fraser and Gordon (1994) remark: 'We find no pejorative uses. It is a weighty, monumental, humanist word'. However, the history of citizenship has been one of terrible exclusions, stemming from the denial of respect, rights, dignity and even humanity by some groups to others. Indeed, from its earliest inception, citizenship has been as much about exclusion as inclusion.

This article explores these simultaneous processes of inclusion and exclusion as they have occurred in different places and at different times in order to understand better the vision of society, the material interests and the notions of identity, which have helped to delineate different understandings of the concept. This is no easy task. Even a preliminary reading of the vast literature on citizenship, spanning the experiences of ancient Athens, the Roman Empire, medieval Europe, the advanced industrialised countries, colonial and post-colonial states, makes it clear that while the idea of citizenship is now nearly universal, ideas about citizenship are not, and never have been.

The aim of this article is to contribute to the development of a research agenda on the theme of 'inclusive citizenship'. While it will touch briefly on the history of the concept, and its practice in different places and times, the main substance of the article is concerned with some of the challenges it presents in the context of poorer Southern countries today. A preliminary clarification on the use of the term 'citizenship' here is necessary. Conventionally, citizenship has been traced to the rise of the nation state and taken to refer to membership of the nation state and the formal duties and rights which membership carries (Shapiro 2000). This understanding has been contested by those who point out that such membership may mean little to its members in contexts compared with other forms of affiliation with which they identify.

However, here, the concern is with this formal notion of citizenship, in order to investigate the extent to which it meshes with, contradicts, or is marginal to other forms of membership that may matter more. The concept of 'inclusive' citizenship is taken to refer both to people's ability to claim their legally recognised rights on an equal basis as well as to the extent to which that law deals with them in a way that guarantees their equality. Forms of exclusion and violations of rights which occur in the context of movements, or attempted movements, by people between nation states, is an important topic in its own right and will not be touched on here.

\section{Citizenship and exclusion: a historical perspective}

From Athens to the Enlightenment: changing notions of citizenship

In its earliest incarnation in the ancient city-state of Athens, the concept of citizenship implied a 'community of equals'. However, the community in question was a highly bounded one. Only those men with the material means, personal breeding and

\footnotetext{
*This article was first published in the IDS Bulletin Volume 33 Number 2 (2002) 'Making Rights Real: Exploring Citizenship, Participation and Accountability' edited by John Gaventa, Alex Shankland and Joanna Wheeler. (C) Institute of Development Studies 2002
} 
leisure to perform their civic duties counted as citizens. Excluded were women and slaves whose domestic labours freed citizens to participate in public life. Citizenship in medieval Europe was also highly selective, confined to residents of the city who had freed themselves from feudal relations of servitude. Outside the city, feudal relationships, based on 'private-law' identities such as serf, villein, vassal, lord and so on, continued to govern social life (Walzer 1989).

The ideas of the Enlightenment with its assertion of free will and individual conscience brought modern ideas about citizenship into existence. The French Revolution remains the most potent symbol of the struggle to establish a notion of citizenship based on civil and political rights against the claims of the feudal order. Citizenship was to be 'the dominant identity of every Frenchman against the alternative identities of religion, estate, family and region ... [and] replace religious faith and familial loyalty as the central motive of virtuous conduct' (Walzer 1989: 211).

While the Enlightenment provided the ideas which fuelled the struggle for citizenship, the dissolution of the older feudal order in the course of industrialisation and the rise of capitalism provided the material conditions under which it was finally won. In Britain, citizenship rights, initially limited to the nobility in their relations with the monarch, were gradually extended to new groups, first of all, the rising propertied middle class, and later to the rest of the adult male population.

As Marshall points out, the concept of citizenship was also made more inclusive through a broadening of the rights of the citizen to include social rights. While membership of village communities, towns and guilds had offered some degree of social security in the pre-industrial period, this had been eroded by the spread of capitalist market relations. However, the diminution of inequality, which accompanied the growing prosperity of the entire society and the compression of the economic distance between classes led to a growing demand for an abolition of inequality, at least with regard to the essentials of social welfare (Marshall 1950: 107).

While Marshall's analysis of the evolution of ideas about citizenship remains one of the most insightful and widely cited, it has also been recognised as partial and incomplete, even in the context he is dealing with. The 'history of citizenship' he describes is, almost exclusively, that of the white, male working class in industrialising Britain. It is an account of a society without empire and without internal inequalities, save those of class (Fraser and Gordon 1994: 93). It is silent on gender and race and on the rights of those whose lands were colonised, whose way of life was disrupted and whose humanity denigrated by the imperial powers, including, of course, Britain.

A somewhat different account of rights and citizenship emerges in the context of the USA. While exclusion in the European context had been justified on the basis of the inherited feudal privilege, citizenship in America was guaranteed by a constitution which drew on the ideas of the social contract theorists, including that of the natural rights of 'the people'. Exclusion could therefore not be treated as a taken-for-granted aspect of the social order; it had to be actively justified through the ascription of various forms of deficiency. When working class men were initially denied the status of citizen, it was on the basis of a presumed association between 'prudence, probity and possessions'. Those without property, it was held, had no stake in the common good.

\section{Justifications for exclusion took on a more} primordial form when they were bound up with socially ascribed identities, such as those of race and gender: 'nature had made women so weak as to require male protection and blacks so stunted that slavery was their true condition' (Shklar 1991: 49). The denial of the vote to the black population on the basis of lesser intrinsic worth continued even after the abolition of slavery. While the 15th Amendment to the American constitution finally extended the suffrage to black men, a variety of 'unruly practices', including 'grotesque registration requirements, literacy tests, poll taxes, grandfather clauses, white primaries, and more chicanery than they could possibly defeat' (Shklar 1991: 55), served to subvert their political rights in the South for several decades thereafter.

Women, black as well as white, continued to be denied civil and political rights long after the franchise had been extended to black men. The common law of coverture meant that married women did not exist legally as independent individuals, but were placed under the 'cover' of their 
husbands who, as head of household, represented them in the public domain. As a result, women could not own property or make contracts without their husbands' consent and were denied free access to education and employment and custody over their children. It was not until the mid- to late nineteenth century that women began to enjoy some measure of civil rights and not until the twentieth century that they were given the franchise.

\section{Citizenship and empire}

The other telling silence in Marshall's account of citizenship in Britain is on the rights of the colonised, an ironical omission in an era when Britain was the leading imperial power. Relationships between different imperial powers and their colonised subjects had obvious differences but also remarkable similarities. Mamdani's explanation for this is to the point:

... the colonial state was in every instance a historical formation. Yet its structure everywhere came to share certain fundamental features... because everywhere the organisation and reorganisation of the colonial state was a response to a central and overriding question: the native question. Briefly put, how can a tiny and foreign minority rule over an indigenous majority? (Mamdani 1996: 16).

The colonial powers drew on a variety of sources, including their experiences and those of others. Hailey's discussion of a system of law for colonial Africa, for instance, draws on the experiences of imperial Rome as well as of the British in India:

Expressed in the briefest of terms, the chief problem of Rome was one of assimilation, and in this respect the Latin mind tended to regard identity of legal rights as a more important element than the equality of political powers. The problem of the British in India was primarily to find a system of law which would avoid emphasising the fact that the country was passing under the domination of a Power professing an alien faith (cited in Mamdani 1996: 49).

It was, in the end, indirect rule, 'association, rather than assimilation', that became the hallmark of colonial rule. Even the French who began by granting citizenship to the inhabitants of their colonies soon found that native cultural assimilation led to 'a resurgence, rather than a subordination', of native political demands. They soon learnt the value of 'association'. However, as Mamdani points out, it was the British who were first to realise the 'authoritarian possibilities in indigenous culture' for attaining hegemonic domination of their subjects (Mamdani 1996). They constructed the colonial edifice on pre-existing arrangements, institutions and identities, but in ways which promoted their goal of hegemony (Bose and Jalal 1998). Customary law and traditional authority may have been invoked to support the hierarchical ordering of society, but the customs and traditions in question were largely 'invented' ones, re-interpretations and reifications which served the imperial project. The history of colonial strategies in both India and Africa is testimony to this strategy.

Prior to colonialism, both regions appear to have been characterised by considerable heterogeneity in economies and cultures, and matching assortments of political arrangements. In the absence of a central state, authority was dispersed within the community and legitimated by customs of caste, clan, kinship and so on. The colonial endeavour, in each region, was to codify, and in the process, to re-interpret and reify, customs and practices which had hitherto been fluid, shifting and capable of accommodating a diversity of local circumstances and needs. In each, the effect was to set up separate 'communities', each governed by its own customs and traditions, alongside a civil society, with a modicum of civil rights, in which selected representatives of the colonised groups interacted on unequal terms with the representatives of the colonial powers. In each context, political power was absorbed into the centralised state apparatus of colonial rule that replaced the diffuse and diversified political arrangements that had existed previously.

In the Indian context, the British were able to use various classification and codification practices to construct economic, religious and caste categories, which then became the basis on which they distributed differential patronage. The privatisation of land through the Permanent Settlement Act created a powerful landlord class, loyal to British interests. In addition, British scholars and officials, with the aid of native 'experts', set about codifying the religious 'laws' of the different communities to provide the basis for governing their personal lives. These personal laws referred to those principles and 
practices which governed relationships within the private sphere of the family, covering such matters as marriage, divorce, maintenance, guardianship of children, adoption, succession and inheritance. They were seen as specific to, and separate for, different religious communities.

However, the process of codification relied on the interpretations of a small privileged group within each religion, Koranic and Brahmanaical priests, scholars and clerics, who not only often disagreed with each other, but whose interpretations bore little relationship to the far more fluid and syncretic practices which had prevailed in local communities beyond the reach of the Mughal court (Bose and Jalal 1998; Mukhopadhyay 1998). In other words, '[w] hat British judges recognised as authentic was "sastric" law in the case of Hindus and interpretation by a cadi in the case of Muslims' (Menon 1998).

The adoption of religious law in the personal sphere was intended to placate conservative opinion within the different religious communities, and win their support for the colonial rulers. The British also adopted the principle of granting separate electorates to 'majority' and 'minority' religious communities in both local and provincial bodies. The effect of this was to solidify divisions along religious grounds, and to unify groups who were geographically and culturally dispersed, but shared a common religion.

Caste was the other major category that became politicised during colonial rule. In principle, Hinduism acknowledges four main castes. In practice, these are subdivided across the subcontinent into many thousands of sub-castes. The lowest rung of the ladder within each local hierarchy is occupied by the untouchables, considered outside the caste system, and associated with the most stigmatised occupations within their societies. Just as the census enumerators had helped to establish the existence of supra-local categories organised along religious grounds, so the enumeration process also helped to construct a supra-local 'depressed' or 'exterior' caste category.

This had enormous implications, carving out an ideological space within which hitherto geographically scattered and culturally differentiated groups could be constituted as a legitimate social category on the basis of their shared subordinate status. '... it was then a matter of political concession rather than ideological imagination to treat them as entitled to the kind of advantages bestowed on other groupings' (Mendelsohn and Vicziany 1998). The politicisation of this ascribed identity became evident in the demands of 'untouchable' leaders that they be treated as a social minority comparable to the Muslims and provided with reserved seats in legislative bodies.

By giving differences within the population far greater significance than they might have warranted, and constructing artificial and unstable unities, British authorities sought to pre-empt the possibility of a unified resistance to their rule. These differentiated categories became the basis on which political claims were made and recognised. When the British conceded first nominated, and later elected, representation by Indians to local legislative councils, the basis of representation was that of 'group', rather than 'individual' interests, initially of the landlord classes and later of religious and caste communities. And when the Indian National Congress fought for independence, 'liberty was understood not as an individual right, but as a nation's collective right to self-determination' (Khilnani 1998).

The same divisive strategies were also in evidence in the very different context of sub-Saharan Africa. Indeed, the earlier experience in India served to shape colonial rule in Africa:

European rule in Africa came to be defined by a single-minded and overriding emphasis on the customary. For in the development of a colonial customary law, India was really a half-way house. Whereas in India, the core of customary law was limited to matters of personal law, in Africa it was stretched to include land ... Just as matters like marriage and inheritance were said to be customarily governed, so procuring basic sustenance required getting customary access to communal land ... With this development, there was to be no exit for the African from the world of the customary (Mamdani 1996: 50).

One reason for this brief digression into the colonial construction of 'community' is that, however 'imagined', the boundaries that were constructed, and however 'invented' the customs and traditions that defined them, these became 'real' in the course of time. They were assimilated into the world-views of their members and became the basis on which 
they acted politically. And they continue to shape state-citizen relationships in the post-colonial era.

\section{The materiality of citizenship The materiality of citizenship: the Western experience}

This rather truncated and selective history of citizenship has been provided partly in order to understand what it means, and how it came about, but also to make the point that the diverse ways in which citizenship is thought about and practised in different times and different places are critically bound up with prevailing material realities and associated ideas about personhood. In this section, the focus is more specifically on these aspects in order to consider in very broad terms how they help to influence contemporary patterns of inclusion and exclusion. For the purposes of this analysis, the article is limited to a somewhat stylised representation of these differences through a contrast of 'Western' and post-colonial experiences.

The idea of citizenship as a way of defining the place of the individual in society evolved in the Western context as part of a series of changes which served to erode earlier definitions. ${ }^{2}$ In traditional precapitalist societies, claims to resources were generally grounded in variations of the 'moral economy', which served to keep individual self-interest in check. Social relationships were characteristically 'quasipermanent', non-voluntary and hierarchical arrangements, which required subordinates to obey and super-ordinates to protect. The disposition of property and other resources was based on a variety of relationships, including those of kin. Ounership tended to be a matter of divided and overlapping claims to various kinds of access and use, rather than of clear-cut individual property rights. The extended notion of family gave a wide range of kinfolk, as well as neighbours and villagers, some degree of economic responsibility for each other.

Prevailing notions of personhood reflected these material realities. 'Relationally defined statuses were cast as prior to, or contemporary with individuals and constitutive of their entitlements and obligations' (Fraser and Gordon 1994: 96). There was no legal recognition of 'individuals' as bearing rights which preceded, and were independent of, their place in a status hierarchy: 'it was an ontology that had room for masters and subjects, but no place for citizens' (Fraser and Gordon 1994). The emergence of the individual as citizen, a sovereign human being, equal to all others, subject only to the laws of the land and the forces of the marketplace, was a product of the ideas of the Enlightenment, with its focus on individual consciousness and free will, combined with the material transformations associated with the spread of market relations, the dissolution of landed privilege and the rise of a new, property-owning middle class. Both sets of changes represented major challenges to pre-existing notions of personhood.

The privatisation of land, for example, deprived the rural population of their customary rights of tenancy and use, but also freed them from customary obligations, so that they could enter into contracts to sell their labour in the marketplace. The reform of traditional poor relief weakened established patterns of community support, further detaching labour from the support of kin and community. Civil rights expanded at the expense of customary claims and obligations. Whereas previously, all social relations had been formed from, or modelled on, kinship, such relationships shrank in the course of industrialisation until they were confined to, and identified with the 'private sphere', the sphere of custom, norm and sentiment.

Elsewhere in society, the expansion of generalised commodity exchange, and the emergence of the modern state, gave rise to an 'impersonal' public sphere, where the laws of the land and the forces of the marketplace prevailed. Civil society, and the practice of citizenship, became part of this newly delineated space where contract had replaced custom: 'resources were exchanged for exact equivalents in discrete, monetised transactions between self-interested independent individuals' (Fraser and Gordon 1994).

As the model of the contract gained ascendance over a progressively larger share of human relations, the range of socially permissible alternatives gradually narrowed, so that residual forms of exchange, those which were neither contractual nor familial, appeared unilateral and voluntary, entailing neither entitlement nor responsibility. Classified as charity, such exchanges positioned the giver as morally creditable and the recipient as stigmatised. This was the model of exchange that underpinned the reformed poor laws, which provided a basic modicum of social assistance to those in need on condition they gave up their rights as citizens. 
However, the gradual extension of franchise beyond the propertied classes also gave rise to demands that labour should not be treated as simply another 'commodity' and that the working man required a certain basic minimum of social security in order to exercise the full civil and political rights of citizenship. Whereas civil-political rights had promoted the 'negative freedoms' necessary for the pursuit of profit untrammelled by the constraints of custom, tradition and moral economy, a new set of social rights sought to create the 'positive freedoms' necessary for those without property to participate fully as citizens. These did not rule out inequalities per se, but they did reduce inequalities in the capacity to act as citizens.

It should be noted that this version of social rights largely emerged out of the social democratic traditions of the European states. As Fraser and Gordon (1994) point out, the greater individualism which characterised American culture offered little space for social rights and the implied obligations of individuals to contribute to the collective welfare.

Nevertheless, the historical evidence tells us that the emergence of liberal notions of citizenship, premised on the model of free and equal citizens, took place in the context of a series of major material and ideological upheavals, the 'great transformation' described by Polanyi (1944): the decline of feudal property relations, the rise of capitalist markets and the modern state, the growing individuation of ideas of personhood, the real and ideological separation of the different spheres of society, encapsulated in the separation of the 'public' sphere of market, state and civil society and the 'private' sphere of family, kinship and community. These transformations were accompanied by the development of institutional machineries to uphold the emerging rule of law. Though discrimination in access to rights, resources and recognition on the basis of ascribed characteristics still continues in these countries, the principle of individual rights and equality before the law is one that has been firmly established and accepted.

\section{The materiality of citizenship: the post-colonial experience}

The experiences of the colonised countries form a marked contrast to this scenario. Here the modern state was founded in the context of colonial rule and dedicated to its defence and prosperity rather than to the development of the local economy or social redistribution. The practice of citizenship by the colonial powers at home bore very little relationship to their practice in their colonies. As a result, not only did they fail to challenge pre-existing hierarchies based on tradition, custom and 'moral economy', they actively strengthened and reified them through the defining powers of a modern state apparatus and a codified system of law. Consequently, colonised populations achieved national independence organised as religious, ethnic and tribal communities with immutable interests and collective rights, 'apparently eternal and enduring elements of their societies', rather than as individual and free citizens.

Although it was hoped that independence would bring about an expansion in material prosperity and political freedoms, liberal notions of citizenship were not part and parcel of the struggle for independence. As Khilnani (1998) points out, the constitutional right to universal suffrage did not emerge from popular pressure within Indian society. It was upheld by a small intellectual elite who hoped that the different processes that had unfolded in slow sequence, often over centuries, in the West, and which had formed the material conditions for their prosperity and freedoms could be condensed into a rapid simultaneity in India (Khilnani 1998: 65).

This did not happen. A modern state and universal franchise were put in place, but the social and economic changes that had given rise to these political institutions in the West occurred only unevenly. Limited success with industrialisation, the very gradual spread of market relations, the continued gulf between urban and rural life, the incapacity or unwillingness of the state to provide for the social welfare of the majority of its citizens, and its capture by powerful elites, all meant many of these pre-existing social relationships and the inequalities which they embodied, survived intact, or only marginally transformed, in the postindependence era.

The idea of citizenship as rooted in an ontology of personhood which recognises individuals as bearing rights which are prior to, and independent of, their place in status hierarchies, still has only shallow roots in many of these societies. Relationally defined statuses continue to be cast as prior to individuals and hence constitutive of their entitlements and obligations. Kinship remains a central organising institution, structuring politics, religion, economy and social relationships, and rendering the distinction 
between public and private irrelevant. Individuals continue to be classified in terms of their kinship roles and relationships and their place within the community. Where market relations spread, and the role of the state expanded, kinship may have been partially displaced from the centre of all social relationships, but the boundaries between public and private remained weak and fluid. And where the state remained weak and socioeconomic rights were either missing or had little relevance to major sections of society, kinship and community relations continued to provide the 'anchor for security' for individuals (Joseph 1997).

This is the situation that continues to prevail in many post-colonial states. The adoption of certain formal rights, with neither the commitment to the obligations which correspond to these rights, or the institutional machinery which would give them substance, make such rights formal, rather than real, and enjoyed with varying degrees of certainty by the population. The highly partial, incomplete and fragmented notions of citizenship which result often serve to reproduce, rather than disrupt, the socially ascribed statuses of kinship, religion, ethnicity, race, caste, gender and so on in the public domain.

It may be argued that these differentiated notions of citizenship resonate more closely with the cultural contexts in which they occur, than do imported ideas of universal individual rights. They correspond to the hierarchies of affiliation which prevail and acknowledge the implications of diversity and difference in ways that are likely to be overlooked in more universalist notions of citizenship. On the other hand, and less positively, it can also be argued that differentiated notions of citizenship negate the very forms of agency that the idea of citizenship was intended to promote and keep alive the very forms of inequality it was intended to negate. In the next section, some of the different ways in which prevailing ideas about personhood, identity and affiliation fracture the rights of citizens and lead to exclusionary outcomes are highlighted. These in turn suggest themes for research into inclusive citizenship.

\section{Challenging citizenship Citizenship and political contestation}

Attempts to formulate citizenship rights and duties are fraught with difficulty in any context characterised by diversity. However, they are particularly fraught in post-colonial societies in which pre-existing differences within the population have been exacerbated or artificially suppressed by the strategic manoeuvrings of colonial powers. Attempts to address this problem through differentiated principles of citizenship which seek to balance local and national interests, individual and collective rights, have given rise to their own set of problems in the form of persisting conflicts of interests and loyalties. These may take ethnic, religious and other primordial forms, but they are essentially political conflicts about the nature and boundaries of citizenship.

In Nigeria, citizenship is associated with a definition of indigeneity based on lineage. To be born and to have an entire working life in a particular state does not qualify an individual as an 'indigene' of that state. Instead, they can only exercise certain citizenship rights, including election to public office in the ancestral home state, irrespective of the strength of ties retained with that home. The principle of 'autochthony' ignores the historical process of integration, inhibits any contemporary tendency towards integration and creates a situation of effective dual citizenship in many parts of the country, regardless of how long, and for how many generations the individuals may have been resident in the community to which they are not "indigenous", (Mustapha 1997: 216).

In Kenya, contested notions of citizenship illustrate the twin problems of defining the 'national interest' and reconciling it with group interests. For the larger ethnic groups (the Kikuyu and Luo), a majoritarian electoral system offers control over the centralised apparatus of the post-colonial state and new opportunities for advancement. For the minority ethnic groups, however, this model of democracy consigns them to the status of a permanent minority. Their interests are better served through majimboism or regionalism, which would decentralise much of state power to autonomous regions, more or less ethnically defined, colonial administrative units.

In India, the intensification of majoritarian democratic politics has seen the erosion of the secular ideals of the constitution, as a new generation of actors have entered the political stage defining themselves explicitly as members of religious communities. Indeed, as Khilnani points out, the very success of India's democracy has engendered the menace of the tyranny of the religious majority, a threat traumatically manifested 
by the destruction of the Babri Masjid at Ayodhya by militant Hindu activists. Conflicts have also occurred along caste lines. While electoral politics has been gradually replacing the 'hierarchy of castes' with a 'democracy of castes' (Kaviraj 2000: 104) in the political arena at least, upper castes have waged war on those below them, often engaging in vicious atrocities on untouchable groups in regions like Bihar. Populist politics has also given rise to attempts to continuously extend the principle of affirmative action, embracing not only the scheduled castes but also other backward castes and even religious minorities, until in almost every case, 'the caste to which an individual belongs becomes a relevant factor in determining his entitlements'.

\section{Citizenship and social inequality}

A second problem of citizenship stems from definitions and practices associated with it which serve to reinforce, rather than eradicate, pre-existing forms of social inequality. The elevation of religious family to the status of public law, as in countries like Lebanon, India, Pakistan and Bangladesh, does not simply offer women different civil rights from men, but also, in contexts of religious diversity, differentiated between women and men from different religious communities. Moreover, as Joseph (1997) points out, it permits members of all social classes, religious and ethnic groups to transport the identities and affiliations of the private sphere of family, kinship and community into the public sphere of state and civil society. These identities and affiliations, rather than those prescribed by law, structure social life and public policy, shaping access to the considerable resources of the state.

Such behaviour reproduces in the 'public' sphere, various forms of inequality which reflect the social relations of the 'private' sphere: 'the distinction between 'elite' and non-elite kinship networks, between rich and poor families within the same kinship networks, between old and young within these families, and between men and women. Resources are distributed on the basis of highly personalised, face-to-face relationships often grounded in real or idiomatic kinship, thus subsidising the control of male/elders over familial females/juniors/ 'poorer relatives ...' (Joseph 1997). As a result, citizens come to expect that demands of kin will take precedence over civil procedures and that their civic rights are conditional on the sets of relationships that they are able to mobilise.

\section{Citizenship and economic dependency}

The third challenge to the practice of inclusive citizenship in poorer countries comes from poverty itself. In situations of extreme scarcity, the formal guarantee of rights is likely to be irrelevant, since seeking redress for the violation of even the most basic of civil rights entails unaffordable costs. However, even the act of contemplating seeking legal redress suggests that a degree of agency has been exercised. A different set of issues comes into view in situations where the absence of the basic survival security impinges so severely on people's agency that it undermines not only their ability to act as citizens, but even the possibility of contemplating such action. These contexts highlight not only the indivisibility of different kinds of rights but also the indivisibility of basic needs and basic rights.

Where people lack the means to meet their daily survival needs, they will only achieve security of livelihoods by binding themselves into highly asymmetrical relationships, receiving a variety of resources essential for their basic needs in return for a variety of resources, which reinforce their patron's dominant status: political or factional support, muscle power in conflict, aid in emergencies, guaranteed supply of labour in peak periods and so on. To understand how these economic relationships impinge on the basic rights of citizens, Smith (1997) points to the phenomenon of power by 'anticipated reaction'.

The threat of withdrawal of support by patron households influences the behaviour of the dependent households in ways that are likely to have implications for their agency as citizens. Such power exists even where there is not clear evidence of attempts by the patron to limit the behaviour of dependent clients. The latter will still feel a pressure to act in what they believe to be the patron's interests rather than their own, including through their voting behaviour, joining or forming associations, exercising freedom of expression. By undercutting the capacity of dependent groups to influence the processes by which their legitimate claims gain the status of formal rights and to participate in the processes by which these formal rights are made 'real', the existence of such vulnerabilities 'undercut the development of any kind of reliable, grounded social practice of respect for human rights generally' (Smith 1997: 11). 


\section{Citizenship and cultural devaluation}

The final challenge to 'inclusive' citizenship relates to issues of culture and identity. Citizenship is a particular way of defining personhood that is in contradistinction to definitions based on status within hierarchical social relationships. It seeks to replace claims based on norm, charity, benevolence or patronage with rights guaranteed by the state. As we noted in the opening quote, 'citizenship as rights enables people to act as agents' (Lister 1997).

However, the formal recognition of rights is not sufficient to turn people into agents. We have noted some of the 'external' constraints that prevent people from realising their rights as citizens. This section touches on others, which are more 'internal' in nature. They relate to the cultural valuations, including self-valuations, of different groups and their implications for their ability to act as citizens. As Lister points out:

... to act as a citizen requires: first a sense of agency, the belief that one can act; acting as a citizen, especially collectively, in turn fosters that sense of agency. Thus agency is not simply about the capacity to choose and act but also about a conscious capacity which is important to the individual's self-identity (Lister 1997: 38).

In other words, to claim one's rights, there has to be a prior belief in one's right to have rights (Isin and Wood 1999).

Citizenship and identity are thus intrinsically connected. Historical evidence tells us that when the rights of certain groups are routinely overlooked or violated and the groups themselves devalued, disparaged or invisibilised by the society in which they live, the denial of recognition can help to reinforce a lack of agency on their part. The importance of this mechanism was articulated over a century ago by Frederick Douglass in his arguments for the enfranchisement of black men in the USA:

'Men are so constituted that they derive their conviction of their own possibilities largely from the estimate formed of them by others. If nothing is expected of a people, that people will find it difficult to contradict that expectation ...' (Frederick Douglass, cit. Shklar 1991: 56).

As Elizabeth Cady Stanton put it, 'To deny political equality is to rob the ostracised of self-respect; of credit in the marketplace; of recompense in the world; of voice in (the choice) of those who make and administer the law; a choice in the jury before which they are tried, and in the judge who decides their punishment (cit. Shklar 1991: 59). And as Shklar added, 'Not to be heard is not to exist, to have no visibility and no place politically' (ibid).

Socially hierarchical relationships, and the inequality of claims, entitlements and personhood which they embody, can be reproduced without a great deal of effort on the part of dominant groups if their dominance goes unquestioned. Unlike the strategic silence on the part of subordinate groups discussed in the previous section, the silence here reflects the absence of questions. The stirrings of a willingness to contest their devalued status on the part of subordinate groups marks the beginnings of their journey from subject to citizen.

\section{Towards inclusive citizenship: an agenda for research}

This article has offered a broad-brush sketch of some of the factors behind the failure of 'inclusive' citizenship in the specific contexts of the South. It makes clear that the constructing of more inclusive forms of citizenship is not amenable to the 'quick-fix' of policy recommendations. It is likely to entail forms of change that go beyond the domain of policy analysis and touch on changes in individual identity and consciousness, as well as protests, movements and prolonged struggles. For the purposes of using research as a means of understanding how these changes are likely to occur, a number of themes emerge out of the analysis in this article.

- Institutions and access. The state, in its various manifestations, is clearly central in determining which needs and priorities are given the status of rights and in their operationalisation. However, beyond the state, a wider range of institutions, including those of the market and civil society, also contribute to the process through their recognition and respect for these rights. Although these are all in principle neutral arenas, in practice they tend to mirror and reproduce the social inequalities which prevail in a given context. This can occur through active discrimination or through unconscious biases. The result is that those that are marginalised within the wider society are also least likely to gain access on equal terms to the rights, resources and protection associated with the status of citizenship. A study 
of the processes by which institutions responsible for both civil-political rights (courts, police, judiciary, political systems) and economic-social rights (state delivery systems, corporate entities, trade unions) give rise to patterns of inclusion and exclusion is clearly critical to an understanding of the dynamics of exclusionary citizenship.

Identity and agency. A second important theme relates to how excluded groups view their exclusion. How people define themselves, and are defined by others, is likely to be critical to their ability to exercise agency on their own behalf, including the agency needed to challenge their exclusion. To what extent do these definitions incorporate the 'right to have rights', the critical precondition for claiming rights? And where such self-recognition is absent or only weakly present, how is it brought into existence? Mendelsohn and Vicziany (1998) attribute an important role to education in promoting the political agency of dalits. They believe that access to education made an important difference at the level of individual identity: 'Formally educated people tend to be different. Education engenders a kind of selfconfidence ... to invest a person with a sense of entitlement to equal treatment in matters of human concern' (Mendelsohn and Vicziany 1998: 263). Elsewhere, however, it has been suggested that formal education reinforces a sense of devaluation and alienation through the promulgation of the dominant values of a society. As Freire has observed in a number of his writings, liberating forms of education come from acts of cognition rather than transfers of information. The various formal and informal, recognised and invisible, ways that excluded groups acquire knowledge and information about their status and rights and the capacity to reflect on their situation, to question it and act on it constitutes a common starting point in attempts to challenge exclusion.

- Associations and collective action. Individuals can, and do, seek to challenge their exclusion from the status and practice of citizenship, but where exclusion is deeply entrenched, such action will have marginal impact. Historically, it is individuals acting collectively that has made most progress in redefining the boundaries of citizenship. Not all forms of group action operate in the political sphere, or in explicitly political ways, but they become 'democratically relevant' when they seek to contest relations of dominance in the sphere within which they operate (Ibrahim 1997: 19). Having a say in the way one is ruled is part of the process by which recognised procedures for participation and accountability are established. Where these are not established by those in authority, they have to be obtained through struggles 'from below'. The third theme suggested by the analysis of this article, is the study of different forms of associations which seek to challenge the exclusions of citizenship in different contexts, the identities and interests which bind them together, the forms of collective action they engage in, what they achieve and the notion of personhood which they embody and promote.

\section{Notes}

1 With thanks to Joanna Howard, Alex Shankland, John Gaventa and Phil Dufty.

2 This account draws largely on Fraser and Gordon (1994). 


\section{References}

Bose, S. and Jalal, A. (1998) Modern South Asia: History, Culture, Political Economy, London: Routledge

Fraser, N. and Gordon, L. (1994) 'Civil Citizenship Against Social Citizenship?', in B. Van Steenbergen (ed.), The Condition of Citizenship, London, Thousand Oaks and New Delhi: Sage: 90-107

Ibrahim, J. (1997) 'Expanding Democratic Space in Nigeria' in J. Ibrahim (ed.), Expanding Democratic Space in Nigeria, Dakar: Codesria

Isin, E. and Wood, P. (1999) Citizenship and Identity, London: Sage

Joseph, S. (1997) 'The Public/Private - The Imagined Boundary in the Imagined Nation/State/ Community: The Lebanese Case', Feminist Review 57: 73-92

Kaviraj, S. (2000) 'Democracy and Social Inequality', in F.R. Frankel, Z. Hasan, R. Bhargava and B. Arora (eds), Transforming Indian Social and Political Dynamics of Democracy, New Delhi: Oxford University Press

Khilnani, S. (1998) The Idea of India, Harmondsworth: Penguin

Lister, R. (1997) Citizenship: Feminist Perspectives, Basingstoke: Macmillan

Mamdani, M. (1996) Citizens and Subjects: Contemporary Africa and the Legacy of Late Colonialism, Princeton: Princeton University Press Marshall, T.H. (1950) Citizenship and Social Class, Cambridge: Cambridge University Press
Mendelsohn, O. and Vicziany, M. (1998) The Untouchables: Subordination, Poverty and the State in Modern India, Cambridge: Cambridge University Press

Menon, N. (1998) 'Women and Citizenship', in P. Chatterjee (ed.), Wages of Freedom: Fifty Years of the Indian Nation State, New Delhi: Oxford University Press

Mukhopadhyay, M. (1998) Legally Dispossessed: Gender, Identity and the Process of the Law, Calcutta: Stree

Mustapha, A.R. (1997) 'Ethnicity and Democratisation in Nigeria: A Case Study of Zangon Kataf', in J. Ibrahim (ed.), Expanding Democratic Space in Nigeria, Dakar: Codesria

Polanyi, K. (1944) The Great Transformation, New York: Rinehart

Shapiro, M.J. (2000) 'National Times and Other Times: Re-thinking Citizenship', Cultural Studies 14.1: 79-98

Shklar, J.N. (1991) American Citizenship: The Quest for Inclusion, Cambridge, Mass.: Harvard University Press

Smith, A. (1997) Human Rights and Choice in Poverty: Food Insecurity, Dependency, and Human Rightsbased Development Aid for the Third World Poor, Westport: Praeger

Walzer, M. (1989) 'Citizenship' in T. Ball, J. Farr and R.L. Hanson (eds), Political Innovation and Conceptual Change, Cambridge: Cambridge University Press 